\title{
Batrachochytrium dendrobatidis in natural and farmed Louisiana crayfish populations: prevalence and implications
}

\author{
Laura A. Brannelly ${ }^{1, *}$, Taegan A. McMahon ${ }^{2}$, Mitchell Hinton ${ }^{3}$, Daniel Lenger ${ }^{4}$, \\ Corinne L. Richards-Zawacki ${ }^{4}$ \\ ${ }^{1}$ One Health Research Group, College of Medical and Veterinary Sciences, James Cook University, Townsville, Queensland, \\ Australia \\ ${ }^{2}$ Department of Biology, University of Tampa, Tampa, Florida, USA \\ ${ }^{3}$ Department of Wildlife, Fish, and Conservation Biology, University of California at Davis, Davis, California, USA \\ ${ }^{4}$ Department of Ecology and Evolutionary Biology, Tulane University, New Orleans, Louisiana, USA
}

\begin{abstract}
The pathogenic chytrid fungus Batrachochytrium dendrobatidis $(B d)$ has been linked to global declines and extinctions of amphibians, making it one of the most devastating wildlife pathogens known. Understanding the factors that affect disease dynamics in this system is critical for mitigating infection and protecting threatened species. Crayfish are hosts of this pathogen and can transmit $B d$ to amphibians. Because they co-occur with susceptible amphibian communities, crayfish may be important alternative hosts for $B d$. Understanding the prevalence and seasonal dynamics of crayfish infections is of agricultural and ecological interest in areas where crayfish are farmed and traded for human consumption. We conducted a survey of $B d$ in farmed and natural crayfish (Procambarus spp.) populations in Louisiana, USA. We found that $B d$ prevalence and infection intensity was low in both farmed and native populations and that prevalence varied seasonally in wild Louisiana crayfish. This seasonal pattern mirrors that seen in local amphibians. As crayfish are an important globally traded freshwater taxon, even with low prevalence, they could be an important vector in the spread of $B d$.
\end{abstract}

KEY WORDS: Alternative hosts - Aquaculture ' Batrachochytrium dendrobatidis · Enzootic · Invasive species · Procambarus clarkii

Resale or republication not permitted without written consent of the publisher

\section{INTRODUCTION}

Amphibians are currently experiencing the greatest decline of all vertebrate taxa (Stuart et al. 2004), and one of the major causes of decline is the chytrid fungus Batrachochytrium dendrobatidis $(B d)$, the pathogenic agent of amphibian chytridiomycosis (Skerratt et al. 2007). $B d$ infects the keratinized tissue of amphibian skin where it disrupts oxygen, ion and water transport and can lead to cardiac arrest and mortality (Voyles et al. 2009).
$B d$ can infect a wide range of amphibian species, though susceptibility to chytridiomycosis varies greatly among species. For example, in Xenopus laevis, Rana catesbeiana (Lithobates catesbeianus) and $R$. pipiens, $B d$ infection generally does not cause disease symptoms (Parker et al. 2002, Schloegel et al. 2010, Chatfield et al. 2013). Researchers have begun to investigate the potential for non-amphibian taxa to act as alternative hosts, which might carry and transmit $B d$ infection. Several non-amphibian species have been demonstrated to harbor $B d$, including, 
Anolis lizards (Kilburn et al. 2011), 3 species of snake (Kilburn et al. 2011), Caenorhabditis elegans nematodes (under laboratory conditions, Shapard et al. 2012), and wading birds (Garmyn et al. 2012). However, none of these studies have demonstrated the ability of the pathogen to complete its life cycle on or in these non-amphibian taxa.

Only 1 study to date has demonstrated that $B d$ can complete its life cycle in a non-amphibian host and transmit $B d$ infection to amphibians. McMahon et al. (2013) found that crayfish (Procambarus spp. and Orconectes spp.) can be $B d$ infected in natural populations, can carry $B d$ for 3 mo in the laboratory, and can transmit infection to tadpoles under laboratory conditions. Crayfish exposed to $B d$ under laboratory conditions also suffered gill damage and mortality, suggesting that $B d$ may pose a health threat to these commercially important animals as well. McMahon et al. (2013) suggest that crayfish may be important in the $B d$-amphibian disease dynamic because presence of crayfish correlates positively with the presence of $B d$ in amphibian communities; crayfish presence is a better predictor of $B d$ presence than the presence of the North American bullfrog $R$. catesbeiana, a purported reservoir species. The North American bullfrog has been suggested as a disease reservoir because it can harbor large $B d$ loads and does not usually develop symptoms of the disease chytridiomycosis (Schloegel et al. 2010).

Procambarus spp. are common in the southeastern USA and are one of the most widely traded freshwater taxa globally, with the majority of individuals coming from Louisiana, USA (Holdich 1993). The crayfish market contributes over $\$ 150$ million annually to Louisiana's economy and over 125000 acres of land are devoted to farming crayfish (McClain \& Romaire 2007). With so much land devoted to aquaculture, many amphibians come in close contact with farm populations of crayfish. Therefore, farmed crayfish may impact the $B d$ infection dynamics of natural populations of the crayfish and amphibians with which they cooccur. Additionally, P. clarkii is traded internationally, and could be a vector for $B d$ spread globally.

We conducted a seasonal field survey for $B d$ infection prevalence in both natural and farmed populations of native crayfish species in Louisiana.
Louisiana was chosen for this study because the state's farms supply a large proportion of the global crayfish market (Holdich 1993, McClain \& Romaire 2007) and natural crayfish populations are widespread and abundant, permitting a comparison of pathogen prevalence and load between farmed and wild animals. Furthermore, data on the prevalence and seasonality of $B d$ in amphibian populations exists for this region (Brannelly et al. 2012), but similar metrics for infection in co-occurring natural and farmed crayfish populations are not available. A clearer understanding of the prevalence, intensity and seasonality of $B d$ in crayfish is needed to better understand the potential impact of $B d$ on crayfish populations, as well as the importance of crayfish as an alternative host for this pathogen, with potential widespread ramifications through the global crayfish trade.

\section{MATERIALS AND METHODS}

\section{Crayfish collection}

\section{Natural populations}

Crayfish Procambarus spp. were collected from southeastern Louisiana (Maurepas Wildlife Management Area, $\mathrm{n}=129$; and Tulane University's F.

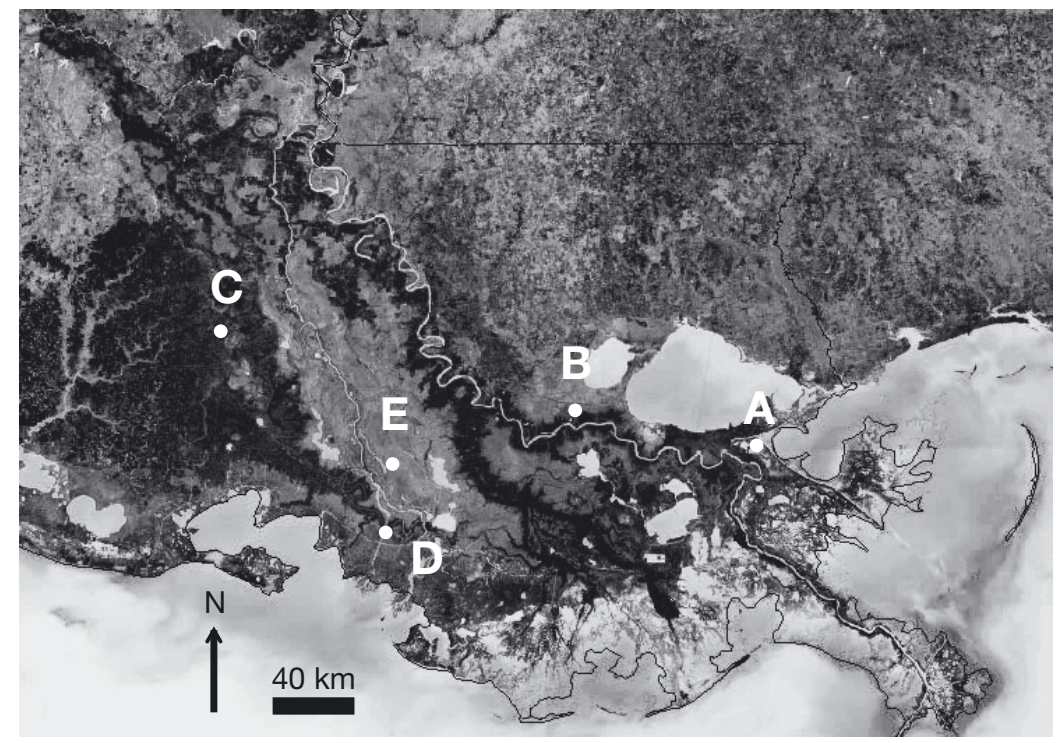

Fig. 1. Southeastern Louisiana showing sampling locations for this study. Letters correspond with site names in Table 1: (A) Tulane University's F. Edward Herbert Research Center in Belle Chase (natural), (B) Maurepas Wildlife Management Area (natural), (C) Lafayette (farm), (D) Morgan City (farm) and (E) Belle River (farm) 
Edward Herbert Research Center in Belle Chase, $\mathrm{n}=$ 142; Fig. 1, and see Table 1). Collection occurred in the spring (February to April) and fall (September and November) of 2012 by sweep netting and using baited minnow traps. Each crayfish was removed from the net or trap individually, using a clean plastic bag, and transported in the sealed bag to Tulane University. There, crayfish were euthanized by freezing at $-20^{\circ} \mathrm{C}$ for a minimum of $2 \mathrm{~h}$. The crayfish sampled in this study were not sampled for any other study.

\section{Farmed populations}

$P$. clarkii were collected live from restaurants in the New Orleans, Louisiana metropolitan area in February and April of 2012. These crayfish were supplied by farms located in Morgan City, Lafayette, and Belle River, Louisiana (Fig. 1, and see Table 1), and from 1 other farm of unknown location within the state. Each restaurant provided 20 to 22 crayfish (total $n=$ 82). Animals were held together in large mesh bags with no water in a 4 to $10^{\circ} \mathrm{C}$ refrigerator at each restaurant for a maximum of $3 \mathrm{~d}$ after delivery from the farms and before we procured them. As the animals were kept communally before we procured them, there was the potential for cross-contamination. When we received the animals, each individual was removed from the communal mesh bag using a clean inverted plastic bag, which was then sealed for transportation to Tulane University. Animals were euthanized by freezing at $-20^{\circ} \mathrm{C}$ for a minimum of $2 \mathrm{~h}$. We were not able to collect farmed crayfish in the fall because the artificial ponds used to farm these animals are drained during this season.

\section{Testing for $B d$ infection}

Crayfish were thawed completely before processing. The inside of the gastrointestinal (GI) tract of each animal was swabbed using a sterile MW113 swab (Medical Wire and Equipment) and $B d$ load was quantified using a real-time polymerase chain reaction (qPCR analysis, see 'DNA extraction and analysis'). The crayfish GI tract was chosen for pathogen load analysis because the fungus is known to infect the GI tract by implanting in the intestinal wall (McMahon et al. 2013). While McMahon et al. (2013) also found $B d$ on crayfish carapace, the histopathology of carapace infection is unknown; therefore, for the purpose of this study, we chose to focus our sampling effort on the inside of the GI tract. A positive
qPCR result indicates the presence of $B d$ DNA in the sample but cannot differentiate the presence of transient DNA from an active infection of the GI tract tissue. This would require histological examination, which was outside the scope of this study. However, McMahon et al. (2013) previously demonstrated, using histopathological examinations of the GI tract, that crayfish of the same genus can become infected with $B d$ and can carry that infection for an extended period of time. While we cannot be certain that the individuals that tested positive for $B d$ in our study had active infections (as opposed to harboring transient $B d$ DNA due to ingestion of contaminated material), in either scenario, the presence of $B d$ could have important implications for understanding the role of crayfish in the spread and dynamics of $B d$ infection in amphibians. As long as the pathogen remains viable on passage through the crayfish digestive system, ingestion of $B d$ by crayfish destined for trade could permit transmission of the pathogen to new areas, even in the absence of an active GI infection. McMahon et al. (2013) showed transmission to amphibians from crayfish that were internally infected under laboratory conditions, which suggests that $B d$ exiting the crayfish digestive system is viable.

To access the GI tract, the abdomen of each carcass was separated from the thorax, and the uropod was separated from the tail and slowly pulled away from the body with the GI tract still attached. The fecal matter inside the GI tract causes PCR inhibition, so it was removed with a sterile swab (MW113). Then, the inside of the GI tract was swabbed, using 30 strokes with a second sterile MW113 swab. GI swabs were kept frozen at $-20^{\circ} \mathrm{C}$ in $1.5 \mathrm{ml}$ microtubes until qPCR analysis. The dissected animal was then placed in a new plastic bag and re-frozen. Gloves were changed between handling the external surface of each crayfish and the internal GI tract, and between each new individual.

\section{DNA extraction and analysis}

To test for the presence of $B d$, we extracted genomic DNA from the GI swabs using the Qiagen DNeasy Blood and Tissue Kit. We followed the manufacture's instructions for animal tissue, using a final elution volume of $200 \mu \mathrm{l}$. Once extracted, qPCR (Applied Biosystems 7500) was used to detect the quantity of $B d$ on each swab. qPCR analysis was carried out following the protocol described by Boyle et al. (2004), except that we added $0.7 \mu$ of bovine serum albumin to each $\mathrm{qPCR}$ reaction to minimize 
inhibition and all wells contained an internal positive control (VIC TM IPC, Applied Biosystems). Positive and negative controls, previously extracted from swabs of known $B d$-positive and $B d$-negative captive Rana catesbeiana, and a dilution series of $B d$ standards (provided by A. Hyatt) were included in each qPCR run. Samples were run in singlicate (Kriger et al. 2006) and DNA was not diluted prior to analysis.

\section{Statistical analysis}

Microsoft Excel was used to calculate $95 \%$ confidence intervals on the proportion of $B d$-positive indi-

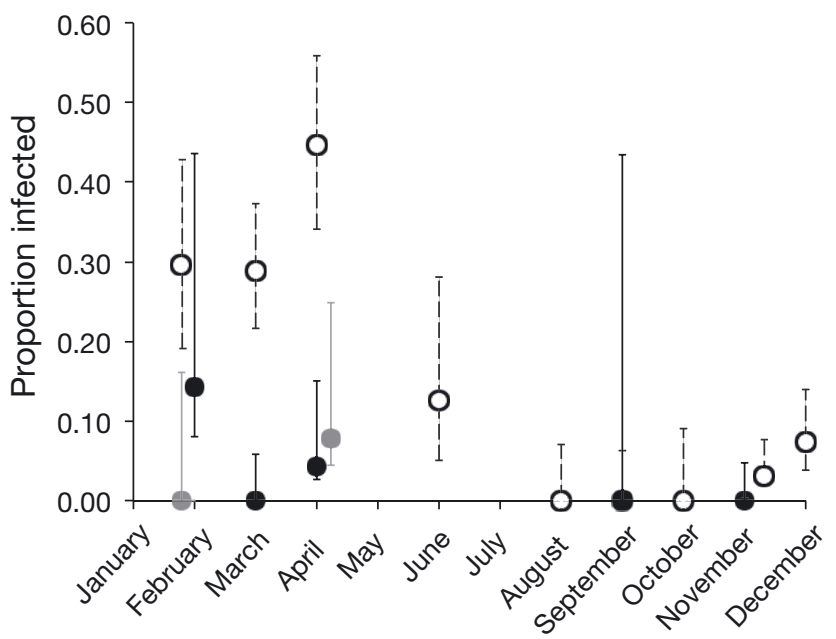

Fig. 2. Proportion of Batrachochytrium dendrobatidis (Bd)positive crayfish sampled in 2012 in southeastern Louisiana. (๑) Wild-caught and (O) farm-collected animals. The proportion of (O with dashed error bars) $B d$-infected amphibians in southeastern Louisiana, sampled in 2010 to 2011, is also shown, modified from Brannelly et al. (2012, their

Fig. 2). The error bars are $95 \%$ confidence intervals viduals following Newcombe (1998). Zoospore equivalents ( $\mathrm{ZE}$ ) in the GI tract in $\mathrm{Bd}$-positive individuals were compared between farmed and natural populations using a 2-tailed $t$-test in SPSS (v21).

\section{RESULTS}

$B d$ prevalence in Louisiana crayfish was seasonal, with higher prevalence in farmed and wild-caught animals in the spring than in wild-caught animals in the fall (Fig. 2, Table 1). This pattern mirrors seasonal trends in $B d$ prevalence for amphibian species in the region, some of which were sampled from the same sites as our wild-caught crayfish samples (Fig. 2, modified from Brannelly et al. 2012). Farmed crayfish tested positive for $B d$ infection in the spring (February and April 2012), with a prevalence of $6.0 \%$ (load: $10.74 \pm 3.96$ (SD) ZE per swab, $\mathrm{n}=5$ ), and no farmed animals were available for testing in the fall. $B d$ was present in natural crayfish populations in the spring with a prevalence of $3.31 \%$ (load: $22.17 \pm 8.15 \mathrm{ZE} \mathrm{per}$ swab, $\mathrm{n}=9$ ), but no $B d$ was detected from those same sites in the fall. Farmed crayfish had a significantly lower ZE than wild-caught animals ( $t$-test: $t_{12}=2.914$, $\mathrm{p}=0.013)$.

\section{DISCUSSION}

The seasonal pattern of $B d$ prevalence in wildcaught Louisiana crayfish in 2012 mirrored that seen in amphibian species sampled in the same region in 2010 and 2011, with higher prevalence during the spring breeding season and no infection detected during the fall season. Prevalences were lower in the

Table 1. Sampling of natural and farmed crayfish. Sites are: (A) Tulane University's F. Edward Herbert Research Center in Belle Chase (natural), (B) Maurepas Wildlife Management Area (natural), (C) Lafayette (farm), (D) Morgan City (farm) and (E) Belle River (farm), and (F) unknown location in Louisiana (farm). Bd: Batrachochytrium dendrobatidis. See Fig. 1 for sampling locations in Louisiana, USA

\begin{tabular}{|c|c|c|c|c|c|c|}
\hline Site & $\begin{array}{l}\text { Latitude } \\
\quad\left({ }^{\circ} \mathrm{N}\right)\end{array}$ & $\begin{array}{l}\text { Longitude } \\
\left({ }^{\circ} \mathrm{W}\right)\end{array}$ & Month & $\begin{array}{l}\text { No. } B d+\text { ind./ } \\
\text { total sampled }\end{array}$ & $\begin{array}{l}\text { Average zoospore } \\
\text { load }( \pm \mathrm{SD})\end{array}$ & Site type \\
\hline A & 29.89 & 89.953 & $\begin{array}{c}\text { February } \\
\text { March } \\
\text { April } \\
\text { September }\end{array}$ & $\begin{array}{l}6 / 35 \\
0 / 62 \\
0 / 40 \\
0 / 5\end{array}$ & $21.67 \pm 11.47$ & Natural \\
\hline B & 30.108 & 90.435 & $\begin{array}{c}\text { April } \\
\text { November }\end{array}$ & $\begin{array}{l}3 / 52 \\
0 / 77\end{array}$ & $13.54 \pm 6.18$ & Natural \\
\hline $\mathrm{C}$ & 30.214 & 92.03 & April & $3 / 22$ & $11.26 \pm 5.49$ & Farm \\
\hline $\mathrm{D}$ & 29.701 & 91.206 & April & $0 / 22$ & & Farm \\
\hline E & 29.888 & 91.206 & April & $2 / 20$ & $4.79 \pm 6.62$ & Farm \\
\hline $\mathrm{F}$ & Unknown & & February & $0 / 20$ & & Farm \\
\hline
\end{tabular}


crayfish than in the amphibians sampled in a given month (Fig. 2). However, since crayfish and amphibians were sampled on different dates and in different years, and in some cases also from different sites, caution should be used in comparing prevalence estimates between these 2 taxa. In this study, we did not find $B d$-infected crayfish in September $(0 / 5 B d+$, $95 \% \mathrm{CI}=0$ to $43.5 \%$ prevalence) or November $(0 / 77$ $B d+, 95 \% \mathrm{CI}=0$ to $4.8 \%$ prevalence) of 2012 , but McMahon et al. (2013) found $B d$ at $17.3 \%$ prevalence in Louisiana crayfish in September of 2011. Our failure to detect $B d$ in the fall could be due to yearly variation in disease prevalence or an artefact of our small sample size early in the fall. Although our study did not support the idea that crayfish act as disease reservoirs during the late summer or fall months, we did detect $B d$ in crayfish during the spring and therefore cannot rule out the idea that these animals may play an important role in disease dynamics. Summer temperatures in Louisiana typically exceed the thermal tolerance of $B d$, and amphibians may clear their infections during this time. It is possible that crayfish are also able to clear $B d$ infections during high summer temperatures, but more research is needed to test this prediction.

Farmed and wild-caught crayfish $B d$ prevalences were similar to each other in the spring, when farmed crayfish were available (Fig. 2). It remains unclear whether the effects of $B d$ on crayfish health should be an important consideration for farmers. $B d$ infection has been shown to cause mortality in laboratoryexposed crayfish (McMahon et al. 2013), but its impact on farmed and natural crayfish populations remains unstudied. While we did not examine animals for pathology, we did find that farmed crayfish had significantly lower $B d$ loads than wild-caught animals. The different conditions these animals experienced directly prior to sampling could also have contributed to the difference in pathogen load. Wildcaught animals were separated upon capture and kept alive only for transport between the field and the laboratory, while the farmed crayfish were kept alive communally in a refrigerated room for up to $3 \mathrm{~d}$ between capture and sampling. However, before concluding that farmed animals have lower pathogen loads than natural populations, a sample of crayfish directly from the farms, analogous to our natural population sampling methods, is needed. While communal refrigerated conditions might have impacted our $B d$ load results, we found that farmed animals, held in analogous conditions to those destined for trade, were positive for $B d$ at a similar prevalence to wild-caught animals. Six percent of the farmed indi- viduals left the farm and were sold for consumption while infected with $B d$.

Minimizing disease transmission between wildlife and farmed animals is important, and this topic has been extensively studied in domesticated animals globally. Wild animals can carry disease and infect individuals in farmed populations, which is particularly concerning for livestock and farm owners (e.g. Mycobacterium bovis, Delahay et al. 2001). Farmed animals can also introduce, spread and maintain infection in natural populations, which can be detrimental to vulnerable species living near farms (e.g. chickens introducing avian malaria into native Hawaiian bird populations, Warner 1968). Both farmed and natural crayfish populations in southeastern Louisiana were $B d$ positive in the spring, which is the time when they commonly share habitats with amphibians. Crayfish infected with $B d$ in close proximity with amphibian populations may play a role in amphibian disease dynamics, especially if infected crayfish are transported to areas that were previously $B d$ free.

Our study found that farmed crayfish were $B d$ positive during the trading season. If farmed crayfish that are globally traded are infected with $B d$, then even a low prevalence of infection could have implications for global amphibian conservation. The international crayfish market is large, with 40000 to $60000 \mathrm{t}$ traded per annum (Holdich 1993), which equates to approximately 0.8 to 1.2 billion individuals. The North American species, Procambarus clarkii, makes up $85 \%$ of all crayfish trade (Holdich 1993). Most of these globally traded crayfish originate from farms in Louisiana (Holdich 1993). Crayfish are the most widely introduced freshwater taxon globally (Helms et al. 2013), likely becoming established after escaping from farms (Gherardi 2006), as farms rarely exercise biosecurity measures to ensure isolation from natural populations. Additionally, P. clarkii is a highly successful invasive species once it escapes its native range. It can reproduce by parthenogenesis, can survive in ephemeral ponds by burrowing deep into mud banks in times of drought (which may help $B d$ persist), and tends to escape from farms and travel quickly to local ponds where it then reproduces (Gherardi 2006). There is already unequivocal evidence that the invasive $P$. clarkii has driven amphibian decline, through predation rather than pathogen spread, in many regions of Europe (Cruz et al. 2006a,b, Cruz 2008, Ficetola et al. 2012). Although there is a clear correlation between amphibian declines and invasion by P. clarkii in Europe, the potential relation- 
ship between amphibian declines, crayfish invasion, and disease has not been explored.

Trade of diseased individuals, whether it be amphibians or other aquatic organisms, might explain the spread of the $B d$ pathogen globally (Fisher \& Garner 2007, Garner et al. 2009, Schloegel et al. 2009, Kolby et al. 2014). While the origin of $B d$ is still unclear, it appears that strains of $B d$ found in parts of Europe are most closely related to strains found in the eastern USA (Rosenblum et al. 2013), which could be explained by the import of invasive North American species like Rana catesbeiana and P. clarkii for consumer purposes. Spain is one place where the role of crayfish as an important alternative host for $B d$ deserves further study, as this country has been experiencing some of the greatest amphibian declines in Europe (Gherardi et al. 2001, Garner et al. 2006). The declines have been attributed to both amphibian predation by the invasive $P$. clarkii as well as chytridiomycosis (Gherardi et al. 2001, Garner et al. 2006). $P$. clarkii were introduced into Spain twice, for the purposes of farming for consumption, from farms in Louisiana between 1973 and 1974 (Hasburgo-Lorena 1986). Since then, crayfish have spread into Portugal and other parts of Europe, either through importation from Spain or migration out of farms. It is possible that $B d$ was introduced into the area through imported crayfish and subsequently spread to natural amphibian populations. Although amphibian trade has been implicated in the global spread of $B d$ (Fisher \& Garner 2007, Garner et al. 2009, Schloegel et al. 2009), even regions devoid of commercial amphibian importation have been exposed to this pathogen. For example, $B d$ has recently been detected for the first time in amphibians coming from Madagascar (Kolby 2014), where North American Procambarus spp. have been introduced into the wild and are now rapidly spreading (Jones et al. 2009). While the correlation between amphibian disease and crayfish presence has not been studied in European, Malagasy, or other ecosystems, our study suggests that farmed $P$. clarkii can carry $B d$, and that creates the risk of zoonotic spill-over if appropriate control measures are not taken.

$B d$ disease dynamics are challenging to understand and predict, and when we consider non-amphibian hosts, the story becomes increasingly complex. There are current biosecurity protocols enacted globally to reduce disease spread through amphibian trade and contaminated field equipment (Green et al. 2009, Murray et al. 2011), but little attention has been directed towards the prevention of $B d$ spread by nonamphibian hosts. In this study, we found that both natural and farmed crayfish populations carry $B d$ infection in Louisiana, and that infection is seasonal in wild-caught animals, similar to the pattern of prevalence seen in amphibian populations in the same region. While prevalence in our study was low, crayfish species may still be an important part of the disease dynamic, especially because they are massdistributed globally. We would argue that a $6.0 \%$ $B d$ infection prevalence in a species that is as widely traded as $P$. clarkii represents a significant risk and deserves to be considered in biosecurity measures.

Acknowledgements. We thank Matthew Robak for help running the qPCR analysis, Matthew Chatfield for help in the laboratory and the field, and Jonathan Kolby for commenting on the manuscript.

\section{LITERATURE CITED}

Boyle DG, Boyle DB, Olsen V, Morgan JAT, Hyatt AD (2004) Rapid quantitative detection of chytridiomycosis (Batrachochytrium dendrobatidis) in amphibian samples using real-time Taqman PCR assay. Dis Aquat Org 60:141-148

> Brannelly LA, Chatfield MWH, Richards-Zawacki CL (2012) Field and laboratory studies of the susceptibility of the green treefrog (Hyla cinerea) to Batrachochytrium dendrobatidis infection. PLoS ONE 7:e38473

Chatfield MWH, Brannelly LA, Robak MJ, Freeborn L, Lailvaux SP, Richards-Zawacki CL (2013) Fitness consequences of infection by Batrachochytrium dendrobatidis in northern leopard frogs (Lithobates pipiens). EcoHealth $10: 90-98$

Cruz J (2008) Collapse of the amphibian community of the Paul do Boquilobo Natural Reserve (central Portugal) after the arrival of the exotic American crayfish. Herpetol J 18:197-204

Cruz MJ, Pascoal S, Tejedo M, Rebelo R (2006a) Predation by an exotic crayfish, Procambarus clarkii, on natterjack toad, Bufo calamita, embryos: its role on the exclusion of this amphibian from its breeding ponds. Copeia 2006: 274-280

Cruz MJ, Rebelo R, Crespo EG (2006b) Effects of an introduced crayfish, Procambarus clarkii, on the distribution of south-western Iberian amphibians in their breeding habitats. Ecography 29:329-338

> Delahay RJ, Cheeseman CL, Clifton-Hadley RS (2001) Wildlife disease reservoirs: the epidemiology of $\mathrm{Myco}-$ bacterium bovis infection in the European badger (Meles meles) and other British mammals. Tuberculosis (Edinb) 81:43-49

Ficetola GF, Siesa ME, De Bernardi F, Padoa-Schioppa E (2012) Complex impact of an invasive crayfish on freshwater food webs. Biodivers Conserv 21:2641-2651

> Fisher MC, Garner TWJ (2007) The relationship between the emergence of Batrachochytrium dendrobatidis, the international trade in amphibians and introduced amphibian species. Fungal Biol Rev 21:2-9

Garmyn A, Van Rooij P, Pasmans F, Hellebuyck T, Van Den Broeck W, Haesebrouck F, Martel A (2012) Waterfowl: potential environmental reservoirs of the chytrid fungus Batrachochytrium dendrobatidis. PLoS ONE 7:e35038 
Garner TWJ, Perkins MW, Govindarajulu P, Seglie D, Walker S, Cunningham AA, Fisher MC (2006) The emerging amphibian pathogen Batrachochytrium dendrobatidis globally infects introduced populations of the North American bullfrog, Rana catesbeiana. Biol Lett 2: 455-459

Garner TWJ, Stephen I, Wombwell E, Fisher MC (2009) The amphibian trade: bans or best practice? EcoHealth 6: 148-151

Gherardi F (2006) Crayfish invading Europe: the case study of Procambarus clarkii. Mar Freshw Behav Physiol 39: 175-191

Gherardi F, Renai B, Corti C (2001) Crayfish predation on tadpoles: a comparison between a native (Austropotamobius pallipes) and an alien species (Procambarus clarkii). Bull Fr Peche Piscicult 361:659-668

Green DE, Gray MJ, Miller DL (2009) Disease monitoring and biosecurity. Forestry, Wildlife, and Fisheries Publications and Other Works. Knoxville, TN, http://trace.tennessee.edu/utk_forepubs/2

Hasburgo-Lorena A (1986) The status of Procambarus clarkii population in Spain. Freshw Crayfish 6:131-136

> Helms B, Loughman ZJ, Brown BL, Stoeckel J (2013) Recent advances in crayfish biology, ecology, and conservation. Freshw Sci 32:1273-1275

Holdich DM (1993) A review of astaciculture: freshwater crayfish farming. Aquat Living Resour 6:307-317

> Jones JPG, Rasamy JR, Harvey A, Toon A and others (2009) The perfect invader: a parthenogenic crayfish poses a new threat to Madagascar's freshwater biodiversity. Biol Invasions 11:1475-1482

Kilburn VL, Ibáñez R, Green DM (2011) Reptiles as potential vectors and hosts of the amphibian pathogen Batrachochytrium dendrobatidis in Panama. Dis Aquat Org 97:127-134

Kolby JE (2014) Presence of the amphibian chytrid fungus Batrachochytrium dendrobatidis in native amphibians exported from Madagascar. PLoS ONE 9:e89660

Kolby JE, Smith KM, Berger L, Karesh WB, Preston A, Pessier AP, Skerratt LF (2014) First evidence of amphibian chytrid fungus (Batrachochytrium dendrobatidis) and ranavirus in Hong Kong amphibian trade. PLoS ONE 9: e90750

Kriger KM, Hero JM, Ashton KJ (2006) Cost efficiency in the detection of chytridiomycosis using PCR assay. Dis Aquat Org 71:149-154

McClain WR, Romaire RP (2007) Procambarid crawfish: life history and biology. Publication No. 2403, Southern Regional Aquaculture Center, Mississippi State University, Stoneville, MS

Editorial responsibility: Louise Rollins-Smith, Nashville, Tennessee, USA
McMahon TA, Brannelly LA, Chatfield MWH, Johnson PTJ and others (2013) Chytrid fungus Batrachochytrium dendrobatidis has nonamphibian hosts and releases chemicals that cause pathology in the absence of infection. Proc Natl Acad Sci USA 110:210-215

Murray K, Skerratt LF, Marantelli G, Berger L, Hunter D, Mahony MJ, Hines H (2011) Hygiene protocols for the control of diseases in Australian frogs. A report for the Australian Government Department of Sustainability, Environment, Water, Population and Communities. Available at: www.environment.gov.au/resource/hygieneprotocols-control-diseases-australian-frogs

Newcombe RG (1998) Two-sided confidence intervals for the single proportion: comparison of seven methods. Stat Med 17:857-872

Parker JM, Mikaelian I, Hahn N, Diggs HE (2002) Clinical diagnosis and treatment of epidermal chytridiomycosis in African clawed frogs (Xenopus tropicalis). Comp Med 52:265-268

> Rosenblum EB, James TY, Zamudio KR, Poorten TJ and others (2013) Complex history of the amphibian-killing chytrid fungus revealed with genome resequencing data. Proc Natl Acad Sci USA 110:9385-9390

Schloegel LM, Picco AM, Kilpatrick M, Davies AJ, Hyatt AD, Daszak P (2009) Magnitude of the US trade in amphibians and presence of Batrachochytrium dendrobatidis and ranavirus infection in imported North American bullfrogs (Rana catesbeiana). Biol Conserv 142: 1420-1426

Schloegel LM, Ferreira CM, James TY, Hipolito M and others (2010) The North American bullfrog as a reservoir for the spread of Batrachochytrium dendrobatidis in Brazil. Anim Conserv 13:53-61

Shapard EJ, Moss AS, San Francisco MJ (2012) Batrachochytrium dendrobatidis can infect and cause mortality in the nematode Caenorhabditis elegans. Mycopathologia 173:121-126

> Skerratt LF, Berger L, Speare R, Cashins S and others (2007) Spread of chytridiomycosis has caused the rapid global decline and extinction of frogs. EcoHealth 4:125-134

Stuart SN, Chanson JS, Cox NA, Young BE, Rodrigues ASL, Fischman DL, Waller RW (2004) Status and trends of amphibian declines and extinctions worldwide. Science 306:1783-1786

> Voyles J, Young S, Berger L, Campbell C and others (2009) Pathogenesis of chytridiomycosis, a cause of catastrophic amphibian declines. Science 326:582-585

- Warner RE (1968) The role of introduced diseases in the extinction of the endemic Hawaiian avifauna. Condor 70 : $101-120$

Submitted: June 16, 2014; Accepted: October 30, 2014

Proofs received from author(s): December 22, 2014 